\title{
Il Cavaliere del Pappagallo, Introduzione, traduzione e note di Eliana Creazzo
}

\section{Walter Meliga}

\section{Q OpenEdition}

1 Journals

\section{Edizione digitale}

URL: http://journals.openedition.org/studifrancesi/1073

DOI: 10.4000/studifrancesi. 1073

ISSN: 2421-5856

\section{Editore}

Rosenberg \& Sellier

\section{Edizione cartacea}

Data di pubblicazione: 1 novembre 2014

Paginazione: 567

ISSN: 0039-2944

\section{Notizia bibliografica digitale}

Walter Meliga, « II Cavaliere del Pappagallo, Introduzione, traduzione e note di Eliana Creazzo », Studi

Francesi [Online], 174 (LVIII | III) | 2014, online dal 01 novembre 2014, consultato il 18 septembre 2020. URL : http://journals.openedition.org/studifrancesi/1073; DOI : https://doi.org/10.4000/studifrancesi. 1073

Questo documento è stato generato automaticamente il 18 settembre 2020.

\section{(c)}

Studi Francesi è distribuita con Licenza Creative Commons Attribuzione - Non commerciale - Non opere derivate 4.0 Internazionale. 


\section{Il Cavaliere del Pappagallo, Introduzione, traduzione e note di Eliana Creazzo}

Walter Meliga

NOTIZIA

Il Cavaliere del Pappagallo, Introduzione, traduzione e note di Eliana CREAZzo, Soveria Mannelli (CZ), Rubbettino, 2011 («Medioevo Romanzo e Orientale. Testi», 12), pp. 219.

1 Edizione con traduzione italiana e note esplicative di questo tardo romanzo arturiano in prosa (che narra la giovinezza di Artù e le sue avventure, guidato da un pappagallo che lo accompagna) secondo il testo dell'edizione di H. Charpentier e P. Victorin (Paris, Champion, 2004). Una breve ma informata introduzione fa il punto sulla meravigliosa ed esotica queste che il romanzo mette in scena. 